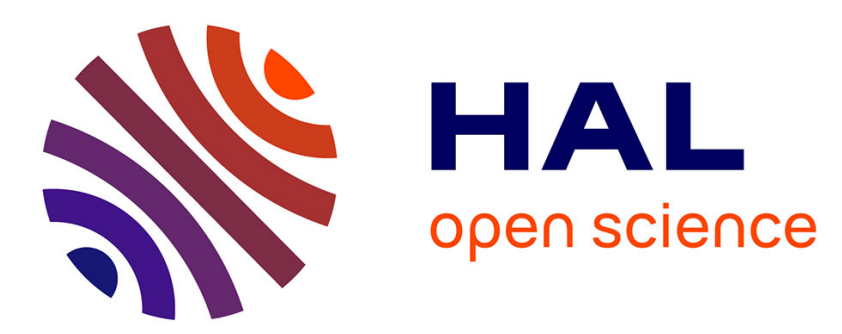

\title{
Higher yield and lower carbon emission by intercropping maize with rape, pea, and wheat in arid irrigation areas
}

Qiang Chai, Anzhen Qin, Yantai Gan, Aizhong Yu

\section{To cite this version:}

Qiang Chai, Anzhen Qin, Yantai Gan, Aizhong Yu. Higher yield and lower carbon emission by intercropping maize with rape, pea, and wheat in arid irrigation areas. Agronomy for Sustainable Development, 2014, 34 (2), pp.535-543. 10.1007/s13593-013-0161-x . hal-01234786

\author{
HAL Id: hal-01234786 \\ https://hal.science/hal-01234786
}

Submitted on 27 Nov 2015

HAL is a multi-disciplinary open access archive for the deposit and dissemination of scientific research documents, whether they are published or not. The documents may come from teaching and research institutions in France or abroad, or from public or private research centers.
L'archive ouverte pluridisciplinaire HAL, est destinée au dépôt et à la diffusion de documents scientifiques de niveau recherche, publiés ou non, émanant des établissements d'enseignement et de recherche français ou étrangers, des laboratoires publics ou privés. 


\title{
Higher yield and lower carbon emission by intercropping maize with rape, pea, and wheat in arid irrigation areas
}

\author{
Qiang Chai • Anzhen Qin • Yantai Gan • Aizhong Yu
}

Accepted: 23 May 2013 / Published online: 26 July 2013

(C) INRA and Springer-Verlag France 2013

\begin{abstract}
Food security has become a global issue, seriously threatening developing countries owing to fast-growing human populations and declining availability of land for agriculture. Increasing crop yields could be achieved by intensive systems, but these usually need higher energy and emit more carbon (C). Here, we studied crop productivity, energy yields, and $\mathrm{C}$ emissions of intercropping versus sole cropping. We tested maize-wheat, maize-rape, maize-pea, and soybean-wheat intercropping, and sole crops as controls in field experiments at Wuwei experimental station in from 2009 to 2011 in a randomized block design with three replicates. We used an evaluation index integrating yield and environmental factors. Results showed a yield increase of $27 \%$ for maize-wheat, $41 \%$ for maize-rape, and $42 \%$ for maize-pea versus sole crops. Water use efficiency increased by $25 \%$ for maize-wheat intercropping over sole wheat, $152 \%$ for maize-rape over sole rape, and $95 \%$ for maizepea over sole pea. The three maize-crop intercrops produced 68,308 , and $256 \%$ more energy yield than did the sole wheat, sole rape, and sole pea crops, respectively. They emitted 42, 52, and $45 \%$ less C per unit of water in 2009, 2010, and 2011, respectively, compared with the sole maize crop. The maize-based intercropping received a the highest
\end{abstract}

Qiang Chai \& Anzhen Qin both authors contributed equally to the study.

Q. Chai $\cdot$ A. Qin $\cdot$ Y. Gan $(\bowtie) \cdot A$. Yu

Gansu Provincial Key Laboratory of Aridland Crop Science, Lanzhou 730070, China

e-mail: ganyantai@126.com

Q. Chai · A. Qin · A. Yu

College of Agronomy, Gansu Agricultural University, Lanzhou 730070, China

Y. Gan

Agriculture and Agri-Food Canada, Swift Current, SK S9H 3X2, Canada evaluation index ( 0.82 out of 1.0) among the systems evaluated, clearly showing that the maize-based intercropping is the most effective and sustainable cropping system for arid irrigation areas.

Keywords Carbon emission · Energy yield · Integrative approach $\cdot$ Soil respiration $\cdot$ Sustainability $\cdot$ Water use efficiency $\cdot$ Zea mays $\cdot$ Triticum aestivum $\cdot$ Brassica campestris $\cdot$ Pisum sativum $\cdot$ Glycine max

\section{Introduction}

Fossil consumption in agriculture contributes to global warming (Kim and Dale 2005). A substitution of fossil input with bioenergy from high-yielding energy crops, such as oilseed rape (Brassica napus L.) or maize (Zea mays L.), can reduce the negative effects of agricultural activities on the environment (Hastings et al. 2008). High-yielding cropping systems usually require more fossil fuel inputs than traditional crop production systems (Tilman et al. 2002); this has raised concerns about the cost of energy and climate change associated with agricultural activities (Grassini et al. 2011). Strip intercropping, where an early-sown cool season crop is "relay" planted with a late-sown warm season crop in strips on the same field, is an "intensive cropping system" (Fig. 1). This practice has been widely used to boost crop productivity (Qin et al. 2013), increase the land utilization ratio (Agegnehu et al. 2008), and reduce weed and disease pressures (Blaser et al. 2007). However, little is known about how strip intercropping affects crop productivity and carbon dioxide $\left(\mathrm{CO}_{2}\right)$ emissions, and there is no scientific information available in regard to the influence of intensive intercropping on the efficiency of a system, such as energy yields per unit of land and carbon (C) emission per unit of water. 

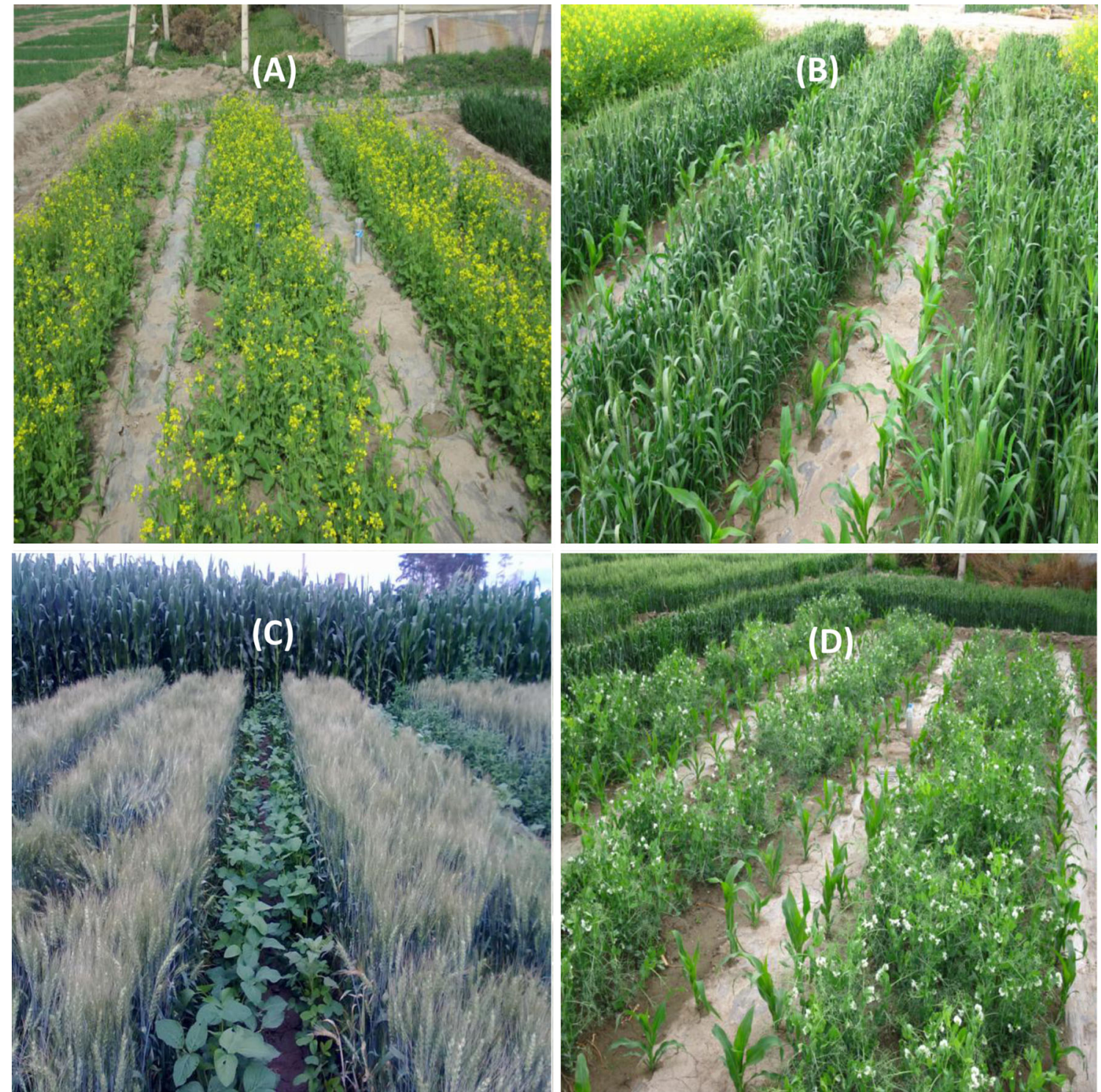

Fig. 1 Intercropping systems tested at Wuwei experimental station, China, with a maize-rape, $\mathbf{b}$ maize-wheat, $\mathbf{c}$ soybean-wheat, and $\mathbf{d}$ maize-pea, at their co-growth period

Crop biomass is a product of solar energy intercepted by crop canopy over a growing season, where solar energy is transformed and stored by $\mathrm{CO}_{2}$ fixation through photosynthesis (Lorenz et al. 2010). Crops with higher energy yields usually emit a higher larger amount of greenhouse gases during their life cycles, but this drawback may be alleviated by the use of legume crops (Lithourgidis et al. 2007). Effective biological nitrogen $(\mathrm{N})$ fixation with legumes means that less $\mathrm{N}$ fertilizer input is required (Fustec et al. 2010), reducing $\mathrm{CO}_{2}$ emissions (Nieder and Benbi 2008), and lowering the $\mathrm{C}$ footprints of agricultural products (Gan et al. 2011a). For example, maize-soybean (Glycine max L.) intercropping emits a significantly lower amounts of greenhouse gases than did maize in monoculture (Oelhermann et al. 2009). Maizewheat intercropping enhances soil carbon $\mathrm{C}$ sequestration, helping to reduce carbon $\mathrm{C}$ emissions (Beedy et al. 2010). It is imperative to determine whether or not intensive cropping systems are sustainable in terms of producing high yields with low $\mathrm{C}$ emissions.

In some arid areas, agriculture largely depends on irrigation, such as the Hexi Corridor of northwestern China, where the annual precipitation is $<160 \mathrm{~mm}$, two-thirds of which falls between July and September. In this typical oasis agricultural region, with abundant sunlight and heat units, but low water availability, intercropping plays a crucial role in balancing high grain production and low water availability (Fan et al. 2013). Yet, in the Hexi Corridor, the traditional net irrigation quota for wheat-maize strip intercropping is estimated to be about $8,400 \mathrm{~m}^{3} \mathrm{ha}^{-1}$ (Fan et al. 2013), a much larger area than what a single crop may require in a growing 
season. In agriculture, over-irrigation causes serious conflicts between water supply and crop demands (Zhang 2007). Therefore, the development of water-saving agricultural systems is an urgent issue for oasis areas. Intercropping has been found to be a means of making good use of limited water (Qin et al. 2013), and is proposed as a means of increasing water use efficiency (Gao et al. 2009).

The objective of this study was to assess the sustainability of strip intercropping in arid irrigation areas by considering key yield- and environment-related factors (grain yield, water use efficiency, land equivalent ratio, energy yield, and $\mathrm{C}$ emissions) together as a whole. Energy yield and $\mathrm{C}$ emissions per unit of water were also determined to make the results of practical value for arid irrigation areas. The central hypotheses of the work were (1) that the choice of crops for intercropping affects the effectiveness of the system such in terms of crop yield, water use efficiency, and $\mathrm{C}$ emissions, and (2) an intercropping system with a higher crop yield does not necessarily give rise to a higher $\mathrm{C}$ emissions, depending, in part, on how the intercropping is managed.

\section{Materials and methods}

The experiment was carried out at the Wuwei experimental station of Gansu Agricultural University, China $\left(37^{\circ} 96^{\prime} \mathrm{N}\right.$, $102^{\circ} 64^{\prime}$ E) from 2009 to 2011. Long-term (1960-2009) annual mean temperature is $7.2{ }^{\circ} \mathrm{C}$, annual precipitation is $156 \mathrm{~mm}$, and annual evaporation $2,400 \mathrm{~mm}$. Annually, the accumulated temperature above $0{ }^{\circ} \mathrm{C}$ is $3,513{ }^{\circ} \mathrm{C}$, solar

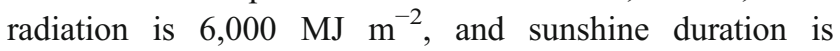
2,945 h. The weather conditions during the 3-year study were described in a previous article (Qin et al. 2013). The soil was an Aridisol (FAO/UNESCO 1988); total nitrogen (N) was $0.78 \mathrm{~g} \mathrm{~kg}^{-1}$, total phosphorous $(\mathrm{P})$ was $1.41 \mathrm{~g} \mathrm{~kg}^{-1}$, and total organic matter was $14.3 \mathrm{~g} \mathrm{~kg}^{-1}$.

\subsection{Experimental design and plot management}

Four intercropping systems (maize-wheat, maize-rape, maize-pea, and soybean-wheat), along with five sole crops (rape, pea, wheat, soybean, and maize), were arranged in a randomized complete block design with three replicates. Plot size was $4.8 \times 10 \mathrm{~m}$. The intercropping was implemented by alternating two crops in strips (Fig. 1). The five sole crops were planted with row spacing in the same manner as the corresponding intercrops. The same species in both sole and intercropping was sown simultaneously on the same day. Maize strips were mulched with plastic films at seeding, an innovative technique for boosting crop productivity in arid environments (Gan et al. 2013). In each of the three study years, a different piece of land was used for the experiment.
Wheat (cv. Yongliang no.4) was planted during the last week of March, rape (cv. Haoyou no. 11) and pea (cv. MZ-1) were planted in the first week of April, and soybean (cv. Zhonghuang no. 3) and maize (cv. Jixiang no.1) were planted during the second week of April. For each crop, the seeding rate was based on seed size and germination of plants per square meter; the plant densities for the intercrops were 16 , $27,183,6$, and 4 plants per square meter for the five corresponding crops. Rape and pea were matured and harvested between 25 June and 5 July, wheat during the last week of July, soybean during the middle of September, and maize at the end of September.

Urea and diammonium phosphate were evenly broadcast and incorporated into the top $30 \mathrm{~cm}$ of soil using a shallow rotary tillage prior to seeding. Rape, pea, wheat, soybean, and maize were, respectively, fertilized at the rates of 85,85 , 225,185 , and $300 \mathrm{~kg} \mathrm{~N} h a^{-1}$, along with $135,135,150,135$, and $225 \mathrm{~kg} \mathrm{P} \mathrm{ha}^{-1}$ each year. The amount of $\mathrm{N}$ fertilizer applied to the two legumes was $20 \%$ less than the requirements for growth based on soil tests when a certain level of $\mathrm{N}$ fixation was taken into account (Qin et al. 2013). No Rhizobium inoculants were used on the legumes, as there were no effective products available on the market. Sole crops and intercrops received the same rates of fertilisation on a per ha basis. $\mathrm{N}$ and $\mathrm{P}$ were applied as base fertilizers to all crops, except maize, which received $30 \%$ of the total $\mathrm{N}$ as a base fertilizer at sowing, $60 \%$ as topdressing at jointing (15-25 June), and the remaining $10 \%$ as topdressing at grain filling (10-25 August). Early-sown crops (rape, pea, and wheat) reached the jointing stage from early May to the middle of May, flowered late in May to the middle June, and podded throughout June. Late-sown crops (soybean and maize) reached the jointing stage from middle-to-late June, flowered during the middle of July, and started podding and filling early in August. As precipitation at the Wuwei experimental station is low $(156 \mathrm{~mm})$, supplemental irrigation was applied 2-5 times (Table 1) per year using a hydrant pipe system. A flow meter was installed at the recharging end to measure the amount of irrigation water applied to each plot over the entire growing season. We considered that crop plants required supplemental irrigation when the average soil water in the $0-30 \mathrm{~cm}$ profile was near $65 \%$ of the field holding capacity.

\subsection{Measurements and calculations}

\subsubsection{Grain yield and water use efficiency}

All plants in each plot were hand-harvested at full maturity, and grain yields (dry weight basis) were determined for sole crops and intercrops individually.

Based on grain yield and the areas each intercrop occupied, the land equivalent ratio (LER) was calculated using the following equation: 
Table 1 Supplemental irrigation dates and irrigation quota at the main crop growth stages at Wuwei experimental station, China, 2009-2011

\begin{tabular}{|c|c|c|c|c|c|c|c|c|}
\hline \multirow[t]{2}{*}{ Irrigation frequency } & \multicolumn{3}{|c|}{ Irrigation date } & \multicolumn{5}{|c|}{ Irrigation quota (mm) } \\
\hline & 2009 & 2010 & 2011 & $\begin{array}{l}\text { Rape } \\
\text { or pea }\end{array}$ & Wheat & $\begin{array}{l}\text { Soybean } \\
\text { or maize }\end{array}$ & $\begin{array}{l}\text { Maize-pea } \\
\text { or maize-rape }\end{array}$ & $\begin{array}{l}\text { Maize-wheat } \\
\text { or soybean-wheat }\end{array}$ \\
\hline First & 2-May & 10-May & 7-May & 70 & 90 & - & 70 & 90 \\
\hline Second & 22-May & 5-Jun & 6-Jun & 70 & 90 & 90 & 70 & 90 \\
\hline Third & 27-Jun & 26-Jun & 28-Jun & - & 82.5 & 82.5 & 62.5 & 82.5 \\
\hline Fourth & 24-Jul & 21-Jul & 22-Jul & - & - & 82.5 & 62.5 & 82.5 \\
\hline Fifth & 17-Aug & 21-Aug & $-^{\mathrm{a}}$ & - & - & 82.5 & 62.5 & 82.5 \\
\hline
\end{tabular}

${ }^{\text {a }}$ The fifth irrigation of 2011 was canceled owing to a large amount of rainfall in late August

$L E R=\frac{Y_{\text {int }} \text { er-cropped } A}{Y_{\text {sole-crop }} A}+\frac{Y_{\text {int }} \text { er-cropped } B}{Y_{\text {sole-crop }} B}$

where $\mathrm{Y}_{\text {intercropped A }}$ and $\mathrm{Y}_{\text {intercropped B }}$ are the yields of the intercrop A and intercrop B, respectively, and $Y_{\text {sole crop A }}$ and $\mathrm{Y}_{\text {sole crop B }}$ are the yields produced by sole crops $\mathrm{A}$ and sole crop B, respectively. An LER $>1$ meant the intercropping had yield advantage over sole crops, and an LER $<1.0$ meant there was no yield advantage (Sullivan 1998).

Water use efficiency was calculated as the grain yield (in $\mathrm{kg} / \mathrm{ha}$ ) produced per unit of evapotranspiration; the latter was the sum of soil water at sowing minus soil water at harvest plus the growing season precipitation and irrigation. Soil water at sowing and harvest was determined using the weighing method (Gao et al. 2009).

\subsection{Energy yield per unit area and per unit of water}

For each crop, energy yield per $\mathrm{m}^{2}$ was calculated by multiplying the grain (and straw) yield (in $\mathrm{kg} / \mathrm{ha}$ ) with their corresponding calorific values (in $\mathrm{MJ} \mathrm{kg}^{-1}$ ):

$E Y=Y_{g} \times E_{g}+Y_{s} \times E_{s}$

where $Y_{\mathrm{g}}$ and $Y_{\mathrm{s}}$ were grain and straw yields (in $\mathrm{kg} \mathrm{ha}^{-1}$ ), and $E_{g}$ and $E_{s}$ were their calorific values (in $\mathrm{MJ} \mathrm{kg}^{-1}$ ), respectively. The grain calorific values for wheat, maize, pea, rape, and soybean are 16.3, 16.3, 16.7, 26.3, and

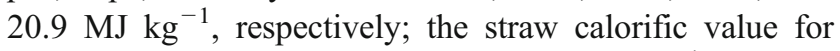
wheat, maize, rape, and pea are $14.6 \mathrm{MJ} \mathrm{kg}^{-1}$, and for soybean it is $15.1 \mathrm{MJ} \mathrm{kg}^{-1}$ (Chen 2002).

The term "energy yield per unit of water (in MJ $\mathrm{ha}^{-1} \mathrm{~mm}^{-1}$ )" was created and used to determine water use efficiency for the production of energy yield; the term was defined as energy yield (in $\mathrm{MJ} \mathrm{ha}{ }^{-1}$ ) per unit of evapotranspiration.

\subsection{Soil respiration and carbon emission}

Soil respiration (in $\mathrm{g} \mathrm{CO}_{2}^{-1} \mathrm{~m}^{2} \mathrm{~h}^{-1}$ ) was monitored 8-9 times from the seeding of the earliest-maturing crop (pea) to the harvest ingot the latest-maturing crop (maize). Consequently, there were 4-5 measurements for pea and rape during their growing seasons plus $4-5$ measurements postharvest; 5-6 measurements for wheat during its growing season plus 4 measurements post-harvest; 6-7 measurements for soybean during its growing season plus 2 measurements postharvest; and 8-9 measurements for the maize during its growing season. Soil respiration was measured using a CFX-2 system (Soil $\mathrm{CO}_{2}$ Flux Systems, Hitchin, UK). The measurements were taken by placing the instrument in the central row of each crop (Luo and Zhou 2006).

Carbon emission (in $\mathrm{kg} / \mathrm{ha}$ ) was estimated using the following equation described by Zhai et al. (2011):

$C E=\sum\left[\frac{R s_{i+1}+R s_{i}}{2}\left(t_{i+1}-t_{i}\right) \times \frac{12}{44}\right] \times 24 \times 10$

where Rs is soil respiration (in $\mathrm{g} \mathrm{CO}_{2}^{-1} \mathrm{~m}^{2} \mathrm{~h}^{-1}$ ), $\mathrm{i}+1$ and $\mathrm{i}$ are the previous and the current sampling date, respectively, and $\mathrm{t}$ is days after sowing.

The term "carbon emission per unit of water (in $\mathrm{kg} \mathrm{ha}^{-1}$ $\mathrm{mm}^{-1}$ )" was created and used to describe the magnitude of C emission (in $\mathrm{kg} / \mathrm{ha}$ ) associated with per unit of evapotranspiration.

An index (as shown in Eq. 6) was created by considering yield- and environment-related factors (grain yield, water use efficiency, land equivalent ratio, energy yield, and $\mathrm{C}$ emission) together as a whole. The index was used to help determine the most productive systems with the least amount of $\mathrm{C}$ emissions. Those yield- and environment-related variables were not dimensionalized, so as to make sure they were compared in a quantitative manner. To support the 
development of the index, the following two equations were first created and used:

$\alpha x_{i j}=\frac{x_{i j}}{x_{\max }}\left(\begin{array}{c}i=1,2,3 \ldots 9 \\ j=1,2,3,4\end{array}\right) \quad$ or $\quad \frac{x_{\min }}{x_{i j}}\left(\begin{array}{c}i=1,2,3 \ldots 9 \\ j=5,6\end{array}\right)$

where $\alpha \mathrm{x}_{\mathrm{ij}}$ is a standardized value $\left(0<\alpha \mathrm{x}_{\mathrm{ij}} \leq 1\right)$ at row $\mathrm{i} \times$ column $\mathrm{j}$ in Table $3 ; \mathrm{x}_{\mathrm{ij}}$ is the corresponding actual value for the treatment $i$ and variable $j$; and $x_{\max }$ and $x_{\min }$ are the maximum and minimum value for each variable.

$$
\beta x_{i j}=\frac{1}{\alpha x_{i j}} \sqrt{\frac{1}{m}} \sum_{i=1}^{m}\left(\alpha x_{i j}-\alpha x_{i j}\right)^{2}\left(\begin{array}{l}
i=1,2,3 \ldots \ldots 9 \\
j=1,2,3 \ldots \ldots 6
\end{array}\right)
$$

where $\beta x_{i j}$ is the coefficient of variation for each variable, and $m$ is the maximum number for $i$ or $j$.

$$
\text { Index }=\sum_{j=1}^{m}\left(\alpha x_{i j} \times \frac{\beta x_{i j}}{\sum_{j=1}^{m} \beta x_{i j}}\right)\left(\begin{array}{l}
i=1,2,3 \ldots . .9 \\
j=1,2,3 \ldots \ldots 6
\end{array}\right)
$$

\subsection{Statistical analysis}

The data were analyzed using statistical analysis software (SPSS 19.0, SPSS Institute Inc. USA), and treatment effects were determined using Duncan's multiple-range test. Owing to significant treatment by year interactions for most of the variables evaluated, the treatment effects were determined for each year.

\section{Results and discussion}

\subsection{Grain yield and water use efficiency}

On average, maize-wheat intercropping and sole maize produced the highest grain yields, averaging $11,650 \mathrm{~kg} \mathrm{ha}^{-1}$, and oilseed rape the lowest at $1,859 \mathrm{~kg} \mathrm{ha}^{-1}$ (Fig. 2). During the 3 years of study, maize-wheat intercropping produced a grain yield of $12.1 \mathrm{t} \mathrm{ha}^{-1}$, an increase of $27 \%$ compared with the average yield of sole wheat and sole maize; similarly, maize-rape intercropping produced a grain yield of $9.6 \mathrm{tha}^{-1}$, an increase of $41 \%$ compared with the average yield of sole rape and sole maize; maize-pea intercropping produced a grain yield of $10.4 \mathrm{tha}^{-1}$, a increased of $42 \%$ compared with the average yield of the two respective sole crops. Using the LER to describe the magnitude of yield increase with intercropping over sole cropping, we found that maize- wheat, maize-rape, and maize-pea had a ratio between 1.16 and 1.48 (data not shown). This suggests that the grain yield produced by intercrops per ha was equivalent to the yield that sole wheat, sole rape, or sole pea would produce on 1.16 and 1.48 ha of land.

Maize-based intercropping had greater water use efficiency than sole crops (Table 2). On average, maize-wheat intercropping had a mean water use efficiency of $19.8 \mathrm{~kg} \mathrm{ha}^{-1} \mathrm{~mm}^{-1}$, or $>25 \%$ compared with sole wheat. Similarly, maize-rape intercropping increased water use efficiency by $152 \%$ compared with sole rape; maize-pea increased water use efficiency by $95 \%$ compared with sole pea. Among maize-based systems, maize-wheat $(19.8 \mathrm{~kg}$ ha $\mathrm{mm})$ had greater water use efficiency than maize-pea $\left(17.7 \quad \mathrm{~kg} \mathrm{ha}^{-1} \mathrm{~mm}^{-1}\right)$ or maize-rape $\left(15.9 \mathrm{~kg} \mathrm{ha}^{-1} \mathrm{~mm}^{-1}\right)$ intercropping; this was because oilseed rape $\left(6.3 \mathrm{~kg} \mathrm{ha}^{-1} \mathrm{~mm}^{-1}\right)$ and pea $\left(9.1 \mathrm{~kg} \mathrm{ha}^{-1} \mathrm{~mm}^{-1}\right)$ had lower water use efficiency than wheat $\left(15.8 \mathrm{~kg} \mathrm{ha}^{-1} \mathrm{~mm}^{-1}\right)$. Our results show that maize-based intercropping is a means of improving water use efficiency in arid irrigation areas.

\subsection{Energy yield per unit area and per unit of water}

Over the study period, maize-wheat intercropping produced an energy yield of 39.0-44.9 $\mathrm{MJ} \mathrm{m}^{-2}$, an increase of 29$43 \%$ compared with the average energy yield produced by sole wheat and sole maize (Table 2). Similarly, maize-rape intercropping produced $25-97 \%$ more energy than sole rape and sole maize, and maize-pea intercropping increased the energy yield by $53-74 \%$ compared with the average energy yield produced by sole pea and sole maize. Maize, as a $\mathrm{C}_{4}$ crop, accumulated significantly greater biomass than did $\mathrm{C}_{3}$ plants, giving an advantage of energy transformation from solar radiation to plant mass (Parkin et al. 2005). Soybeanwheat intercropping (20.3 $\mathrm{MJ} \mathrm{m}^{-2}$ ) had lower (18\%) energy yield than sole wheat $\left(24.7 \mathrm{MJ} \mathrm{m}^{-2}\right)$ because soybean had a lower plant biomass.

Water shortage is becoming an urgent issue in arid irrigation areas, such as where this study was conducted; thus, energy yield per unit of water serves as one of the major criterions for the assessment of the effectiveness of cropping systems. In the present study, cropping systems were categorized into two groups based on energy yield per unit of water. The higher energy yielding group (including maizewheat, maize-rape, maize-pea, and sole maize) had mean energy yields per unit of water of $704 \mathrm{MJ} \mathrm{ha}^{-1} \mathrm{~mm}^{-1}$ in 2009 , $807 \mathrm{MJ} \mathrm{ha}^{-1} \mathrm{~mm}^{-1}$ in 2010 , and $741 \mathrm{MJ} \mathrm{ha}^{-1} \mathrm{~mm}^{-1}$ in 2011 (Table 2). The yields were $83 \%$ (2009), $104 \%$ (2010), and $64 \%$ (2011) greater, respectively, than the mean energy yield per unit of water produced by the lower energy yielding 
Fig. 2 Grain yields of early- and late-sown crops in various intercropping systems in comparison with sole crops at Wuwei experimental station, China. Bars are standard error $(n=9)$ of the mean. The percentages on the right of the error bars mean percent increase of grain yield in intercropping systems compared with the average yield of the corresponding two sole crops

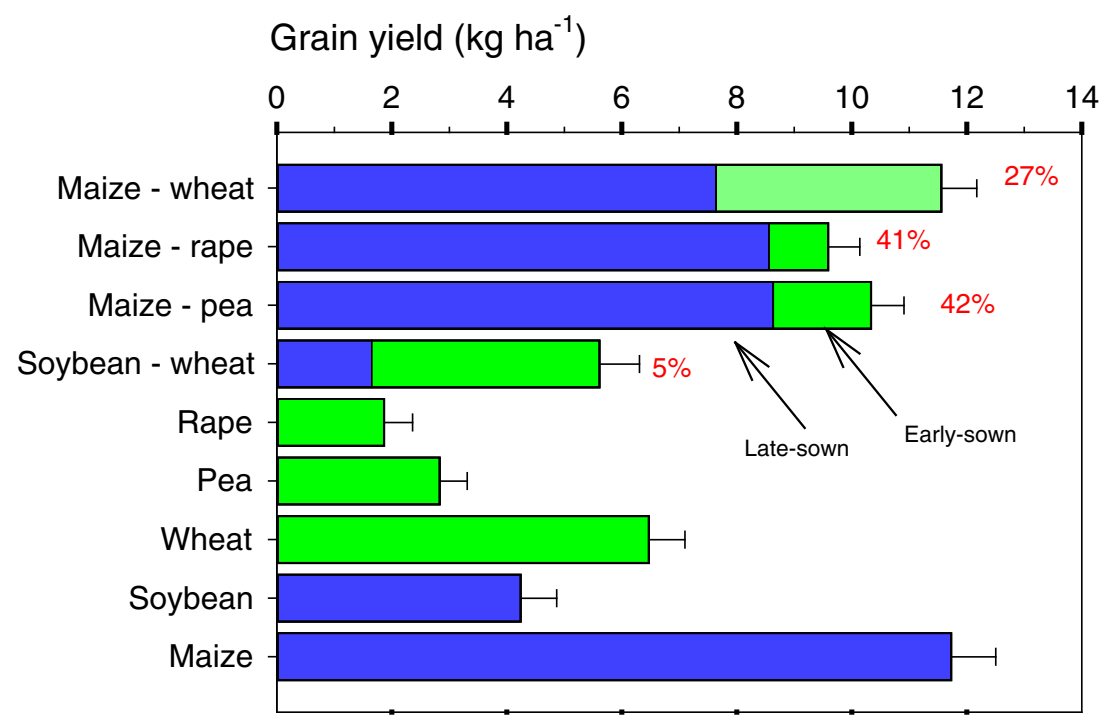

study, soil respiration differed significantly between cropping systems. Maize-rape intercropping had a mean soil respiration of $0.28 \mathrm{~g} \mathrm{CO}^{2} \mathrm{~m}^{-2} \mathrm{~h}^{-1}$ or $51 \%$ less than sole maize; similarly, mean soil respiration of maize-pea intercropping was $44 \%$ less than sole maize; mean soil respiration of maize-wheat was $35 \%$ less than sole maize.

The amount of $\mathrm{C}$ emitted during the cropping season differed significantly between cropping systems (Table 2). Sole maize had the highest $\mathrm{C}$ emission, averaging $4.1 \mathrm{t} \mathrm{ha}^{-1}$ annually. Intercropping significantly reduced $\mathrm{C}$ emissions compared with sole maize. On average, the maize-wheat system emitted $3.1 \mathrm{t} \mathrm{ha}^{-1}$ of $\mathrm{C}$ annually, or $24 \%$ less than sole maize; similarly, maize-pea emitted $2.8 \mathrm{tha}^{-1}$ of $\mathrm{C}$, or $31 \%$ less than sole maize; maize-rape emitted $2.3 \mathrm{t} \mathrm{ha}^{-1}$ of C, or $44 \%$ less than that of sole maize. Soybean-wheat had the lowest $\mathrm{C}$ emissions among the intercropping systems, with an average value of $1.8 \mathrm{t} \mathrm{ha}^{-1}$. These results indicate

Table 2 Water use efficiency, energy yield, and carbon (C) emission for various intercropping systems and the corresponding sole crops at Wuwei experimental station, China, 2009-2011

\begin{tabular}{|c|c|c|c|c|c|c|c|c|c|}
\hline \multirow[t]{2}{*}{ Cropping system } & \multicolumn{3}{|c|}{ Water use efficiency $\left(\mathrm{kg} \mathrm{ha}^{-1} \mathrm{~mm}^{-1}\right)$} & \multicolumn{3}{|c|}{ Energy yield per unit area $\left(\mathrm{MJ} \mathrm{m}^{-2}\right)$} & \multicolumn{3}{|c|}{$\mathrm{C}$ emission per unit area $\left(\mathrm{t} \mathrm{ha}^{-1}\right)$} \\
\hline & 2009 & 2010 & 2011 & 2009 & 2010 & 2011 & 2009 & 2010 & 2011 \\
\hline Maize-wheat & $18.4 \mathrm{a}^{\mathrm{a}}$ & $19.5 \mathrm{~b}$ & $21.5 \mathrm{a}$ & $39.0 \mathrm{a}$ & $40.7 \mathrm{a}$ & $44.9 \mathrm{a}$ & $3.00 \mathrm{~b}^{\mathrm{b}}$ & $2.96 \mathrm{~b}$ & $3.36 \mathrm{~b}$ \\
\hline Maize-rape & $16.2 \mathrm{~b}$ & $16.8 \mathrm{c}$ & $14.8 \mathrm{c}$ & $37.0 \mathrm{a}$ & $42.1 \mathrm{a}$ & $32.2 \mathrm{~b}$ & $2.25 \mathrm{c}$ & $2.12 \mathrm{de}$ & $2.52 \mathrm{c}$ \\
\hline Maize-pea & $16.7 \mathrm{~b}$ & $18.0 \mathrm{c}$ & $18.4 \mathrm{~b}$ & $37.3 \mathrm{a}$ & $40.2 \mathrm{a}$ & $37.6 \mathrm{ab}$ & $2.64 \mathrm{bc}$ & $2.75 \mathrm{bc}$ & $3.05 \mathrm{~b}$ \\
\hline Soybean-wheat & $9.4 \mathrm{c}$ & $10.5 \mathrm{e}$ & $10.5 \mathrm{~d}$ & $18.4 \mathrm{c}$ & $21.8 \mathrm{~d}$ & $20.6 \mathrm{c}$ & $1.76 \mathrm{~d}$ & $1.84 \mathrm{f}$ & $1.90 \mathrm{~d}$ \\
\hline Rape & $4.4 \mathrm{~d}$ & $4.3 \mathrm{~g}$ & $10.2 \mathrm{~d}$ & $7.3 \mathrm{e}$ & $7.8 \mathrm{f}$ & $12.2 \mathrm{~d}$ & $1.62 \mathrm{~d}$ & $1.69 \mathrm{f}$ & $1.80 \mathrm{~d}$ \\
\hline Pea & $8.8 \mathrm{c}$ & $8.6 \mathrm{f}$ & $9.9 \mathrm{de}$ & $11.5 \mathrm{de}$ & $11.3 \mathrm{ef}$ & $9.5 \mathrm{~d}$ & $1.77 \mathrm{~d}$ & 1.88 ef & $1.90 \mathrm{~d}$ \\
\hline Wheat & $15.6 \mathrm{~b}$ & $14.4 \mathrm{~d}$ & $17.5 \mathrm{~b}$ & $23.0 \mathrm{~b}$ & $27.6 \mathrm{c}$ & $23.5 \mathrm{c}$ & $2.19 \mathrm{c}$ & $2.41 \mathrm{~cd}$ & $2.37 \mathrm{c}$ \\
\hline Soybean & $9.5 \mathrm{c}$ & $8.9 \mathrm{f}$ & $8.9 \mathrm{e}$ & $15.3 \mathrm{~cd}$ & $15.9 \mathrm{e}$ & $15.8 \mathrm{~cd}$ & $1.59 \mathrm{~d}$ & $1.61 \mathrm{f}$ & $1.69 \mathrm{~d}$ \\
\hline Maize & $20.9 \mathrm{a}$ & $23.2 \mathrm{a}$ & $18.5 \mathrm{~b}$ & $37.4 \mathrm{a}$ & $34.9 \mathrm{~b}$ & $39.4 \mathrm{ab}$ & $3.85 \mathrm{a}$ & $4.19 \mathrm{a}$ & $4.23 \mathrm{a}$ \\
\hline
\end{tabular}

${ }^{a}$ Means with different letters in the same column are significantly different at $P<0.05$

${ }^{\mathrm{b}} \mathrm{C}$ emissions were estimated using Eq. 3 based on the 8-9 soil respiration measurements during the period from April to September 
that the adoption of proper intercropping systems can significantly mitigate $\mathrm{C}$ emissions from the production of field crops, and that use of diversified cropping systems with cereals intercropped with oilseeds or legumes can potentially reduce negative impacts of agriculture on the environment. A number of studies have shown that the inclusion of legume crops in cropping systems reduces chemical $\mathrm{N}$ input (Fustec et al. 2010), mitigates $\mathrm{CO}_{2}$ emission (Lemke et al. 2007), and lowers the $\mathrm{C}$ footprint of grain products (Gan et al. 2011b).

Sole maize had the greatest $\mathrm{C}$ emission per unit of water among treatments, with a mean value of $7.6 \mathrm{~kg} \mathrm{ha}^{-1} \mathrm{~mm}^{-1}$ (data not shown). Intercropping reduced $\mathrm{C}$ emissions per unit of water significantly compared with sole maize in each of the three study years. In 2009, maize-wheat, maize-rape, and maize-pea intercropping had an average of $3.7 \mathrm{~kg} \mathrm{ha}^{-1} \mathrm{~mm}^{-1}$ of water, or $42 \%$ less than sole maize; similarly, the three maize-based intercrops had $52 \%$ less $\mathrm{C}$ emissions per unit of water in 2010 and $45 \%$ less in 2011 than sole maize. Maize-rape had $52 \%$ less $\mathrm{C}$ emissions per unit of water than sole maize in $2009,43 \%$ less in 2010, and $49 \%$ less in 2011 . The significantly lowered $\mathrm{C}$ emissions with the maize-based intercrops compared with sole maize was partly attributable to the slow accumulation of plant biomass of the early-sown, cool season intercropped rape, pea, and wheat crops (Qin et al. 2013).

\subsection{General discussion}

In the present study, maize-pea and maize-rape intercropping produced similar grain yields as maize-wheat intercropping, but the former did so with $30 \%$ less irrigation than the maizewheat intercropping. Maize-pea and maize-rape intercropping allows sharing of the soil water between the two intercrops during their co-growth period, as pea and rape plants typically have a shallower rooting depth than cereal plants (Gan et al. 2011c). Legume and oilseed plants require less water than cereal plants when they are intercropped (Zhang and $\mathrm{Li}$ 2003). The lowered amount of irrigation means the reduction of fossil input to the production of grain crops, giving rise to a reduction of equivalent $\mathrm{C}$ emissions (Bessou et al. 2011). Aquifers are rapidly depleting in arid irrigation areas owing to over-exploitation of water resources (Zhang 2007). Maize intercropping with oilseed rape or pea can be regarded as a viable option for the development of effective cropping systems in the arid irrigation regions.

Legume-rhizobial associations are an effective solar-driven $\mathrm{N}_{2}$-fixing system, in which atmospheric $\mathrm{N}_{2}$ is transformed into ammonia to fulfill a large portion of the $\mathrm{N}$ requirements for the growth of legume plants (Yang et al. 2010). In addition to meeting a large portion of their own $\mathrm{N}$ requirements, legume plants leave a portion of their biologically-fixed $\mathrm{N}$ in the soil (Khan et al. 2003; Campbell et al. 2006). Also, the soil N contribution is through increased rhizodeposition, and crop roots and nodules that remain in the soil after a legume crop is harvested (Gan et al. 2010). In some cases, mineralized N from the legume roots and nodules can be considerable (Khan et al. 2003), allowing for a more effective synchrony between $\mathrm{N}$ mineralization from legume residues and the peak $\mathrm{N}$ demand of the crops. Therefore, intercropping legumes with cereals can be considered a key strategy in increasing crop productivity, while decreasing production inputs and lowering the $\mathrm{C}$ footprint of agricultural products.

Most published studies have focused on one or two key factors, such as grain yield (Fan et al. 2013), water use

Table 3 Functional components and the evaluation index for assessing the effectiveness and sustainability of various cropping systems at Wuwei experimental station, China, 2009-2011

\begin{tabular}{|c|c|c|c|c|c|c|c|c|}
\hline \multirow[t]{2}{*}{ Treatment } & \multirow[t]{2}{*}{$j i$} & \multicolumn{6}{|c|}{ Functional component ${ }^{\mathrm{a}}$} & \multirow[t]{2}{*}{ Evaluation index } \\
\hline & & 1 & 2 & 3 & 4 & 5 & 6 & \\
\hline Maize-wheat & 1 & 0.91 & 0.90 & 0.99 & 0.89 & 0.52 & 0.53 & $0.80 \mathrm{a}^{\mathrm{c}}$ \\
\hline Maize-rape & 2 & 0.73 & 0.93 & 0.89 & 0.91 & 0.71 & 1.00 & $0.86 \mathrm{a}$ \\
\hline Maize-pea & 3 & 0.81 & 0.96 & 0.92 & 0.96 & 0.58 & 0.58 & $0.80 \mathrm{a}$ \\
\hline Soybean-wheat & 4 & 0.46 & 0.72 & 0.48 & 0.46 & 0.89 & 0.89 & $0.63 \mathrm{c}$ \\
\hline Rape & 5 & 0.29 & 0.72 & 0.22 & 0.44 & 0.96 & 0.88 & $0.54 \mathrm{~d}$ \\
\hline Pea & 6 & 0.42 & 0.72 & 0.26 & 0.50 & 0.88 & 0.56 & $0.52 \mathrm{~d}$ \\
\hline Wheat & 7 & 0.73 & 0.72 & 0.59 & 0.75 & 0.70 & 0.53 & $0.66 \mathrm{c}$ \\
\hline Soybean & 8 & 0.41 & 0.72 & 0.37 & 0.42 & 1.00 & 0.95 & $0.61 \mathrm{c}$ \\
\hline Maize & 9 & 0.95 & 0.72 & 0.89 & 0.98 & 0.40 & 0.35 & $0.73 \mathrm{~b}$ \\
\hline
\end{tabular}

\footnotetext{
${ }^{a}$ The six functional components were (1) water use efficiency, (2) land equivalent ratio, (3) energy yield per unit area, (4) energy yield per unit of water, (5) carbon (C) emission per unit area, and (6) $\mathrm{C}$ emission per unit of water, with each value being in the range of 0 to 1

${ }^{\mathrm{b}}$ The evaluation index was created using the six functional components; a cropping system with a higher index is more effective and sustainable in arid irrigation areas

${ }^{\mathrm{c}}$ Means with different letters in the same column are significantly different at $P<0.05$
} 
efficiency (Blum 2009), or other yield-related traits (Gao et al. 2009), in the evaluation of the effectiveness of cropping systems. There is a lack of knowledge or innovative methodology in integrating multiple factors to have a systemlevel evaluation for crop production systems. This is particularly the case in less developed countries, where the priority is to produce sufficient quantity of grain to meet increasing grain demands, with little attention placed to the systemlevel effectiveness or sustainability. In the present study, we combined several key yield- and environment-related factors, including water use efficiency, land equivalent ratio, energy yield, and $\mathrm{C}$ emissions together to create an evaluation index (Table 3). In an innovative approach, we used the index to evaluate the effectiveness or sustainability of various cropping systems currently adopted in the arid irrigation regions of northwest China. A higher index value means the system is more effective and sustainable. The index revealed significant differences between cropping systems, with the three maize-based intercropping systems having an average index of 0.82 out of 1.0 , significantly greater than the rest of the cropping systems. The three maize-based intercropping systems not only increased water use efficiency, energy yield, and land equivalent ratio, but also reduced $\mathrm{C}$ emissions on both per unit area and per unit of water compared with sole crops. Our results clearly indicate that maize-based intercropping systems are the ones most effective and sustainable in arid irrigation areas.

\section{Conclusion}

Agricultural ecosystems in arid areas are extremely fragile. In recent years, some great efforts have been made in searching for effective and sustainable cropping systems aimed at producing sufficient quantities of grains, while minimizing potential nega tive impacts of agricultural activities on the environment. Published studies mostly concentrated on a single, or a few, factors that would affect the effectiveness and sustainability of a cropping system, with a lack of an integrated approach. Nothing is wrong with this approach, but the results are often biased, without consideration of all relevant factors. In the present study, we created an evaluation index, in which several key yield- and environment-related factors were integrated as a whole. Such an evaluation index serves as an implicit indicator, giving a comprehensive assessment of the effectiveness and sustainability of cropping systems. Farm managers may use this index to distinguish the winners from the losers in choosing the most suitable systems for their farms. Our results clearly showed that maize-based intercropping had an overall greater index over sole crops, and those intercropping not only increased water use efficiency, land equivalent ratio (an indicator of yield advantage/disadvantage of intercropping over sole cropping), energy yield per unit area, and per unit of water, but also decreased $\mathrm{C}$ emissions per unit area and per unit of water. Maize-based intercropping systems are the most effective and sustainable production systems for arid irrigation areas.

Acknowledgments This study was supported by the National Key Technology R\&D Program of China (2012BAD14B10), the National Natural Science Fund (31160265), and the Special Fund for AgroScientific Research in the Public Interest (201103001). The authors also appreciate the assistance of the staff at Wuwei experimental station in managing field plots.

\section{References}

Agegnehu G, Ghizaw A, Sinebo W (2008) Yield potential and land-use efficiency of wheat and faba bean mixed intercropping. Agron Sustain Dev 28:257-263. doi:10.1051/agro:2008012

Beedy TL, Snapp SS, Akinnifesi FK, Sileshi GW (2010) Impact of Gliricidia sepium intercropping on soil organic matter fractions in a maize-based cropping system. Agric Ecosyst Environ 138:139 146. doi:10.1016/j.agee.2010.04.008

Bessou C, Ferchaud F, Gabrielle B, Mary B (2011) Biofuels, greenhouse gases and climate change - A review. Agron Sustain Dev 31:1-79. doi:10.1051/agro/2009039

Blaser BC, Singer JW, Gibson LR (2007) Winter cereal, seeding rate, and intercrop seeding rate effect on red clover yield and quality. Agron J 99:723-729. doi:10.2134/agronj2006.0247

Blum A (2009) Effective use of water (EUW) and not water-use efficiency (WUE) is the target of crop yield improvement under drought stress. Field Crops Res 112:119-113. doi:10.1016/j.fcr. 2009.03.009

Campbell CA, Selles F, Zentner RP, De Jong R, Lemke R, Hamel C (2006) Nitrate leaching in the semiarid prairie: Effect of cropping frequency, crop type, and fertilizer after 37 years. Can J Soil Sci 86:701-710

Chen F (2002) Agricultural Ecology. Press of China Agriculture University, Beijing, pp 261-263

Dyer L, Oelbermann M, Echarte L (2012) Soil carbon dioxide and nitrous oxide emissions during the growing season from temperate maize-soybean intercrops. J Plant Nutr Soil Sci 175:394-400. doi:10.1002/jpln.201100167

Fan ZL, Chai Q, Huang GB, Yu AZ, Huang P, Yang CH, Tao ZQ, Liu HL (2013) Yield and water consumption characteristics of wheat/ maize intercropping with reduced tillage in an oasis region. Eur J Agron 45:52-58. doi:10.1016/j.eja.2012.10.010

FAO/UNESCO (1988) Soil map of the world: Revised legend. FAO, Rome

Fustec J, Lesuffleur F, Mahieu S, Cliquet JB (2010) Nitrogen rhizodeposition of legumes - A review. Agron Sustain Dev 30:57-66. doi:10.1051/agro/2009003

Gan YT, Campbell CA, Jansen HH, Lemke RL, Basnyat P, McDonald CL (2010) Nitrogen accumulation in plant tissues and roots and N mineralization under oilseeds, pulses, and spring wheat. Plant Soil 332:451-461

Gan YT, Liang C, Hamel C, Cutforth H, Wang H (2011a) Strategies for reducing the carbon footprint of field crops for semiarid areas - A Review. Agron Sustain Dev 31:643-656. doi:101007/s13593011-0011-7

Gan YT, Liang C, Wang XY, McConkey BG (2011b) Lowering carbon footprint of durum wheat by diversifying cropping systems. Field Crops Res 122:199-206. doi:10.1016/j.fcr.2011.03.020 
Gan YT, Liu LP, Cutforth H, Wang XY, Ford G (2011c) Vertical distribution profiles and temporal growth patterns of roots in selected oilseeds, pulses and spring wheat. Crop Pasture Sci 62:457-466. doi:10.1071/CP10406 1836-0947/11/060457

Gan YT, Siddique KHM, Turner NC, Li XG, Niu JY, Yang C, Liu LP (2013) Ridge-furrow mulching systems - an innovative technique for boosting crop productivity in semiarid rainfed environments. Adv Agron 118:429-476. doi:10.1016/B978-0-12-405942-9. 00007-4

Gao Y, Duan AW, Sun JS, Li FS, Liu ZG, Liu H, Liu ZD (2009) Crop coefficient and water-use efficiency of winter wheat/spring maize strip intercropping. Field Crops Res 111:65-73. doi:10.1016/j.fcr. 2008.10.007

Grassini P, Yang H, Irmak S, Thorburn J, Burr C, Cassman KG (2011) High-yield irrigated maize in the Western U.S. Corn Belt. II. Irrigation management and crop water productivity. Field Crops Res 120:133-141

Hastings A, Clifton-Brown J, Wattenbach M, Stampfl P, Mitchell PC, Smith P (2008) Potential of Miscanthus grasses to provide energy and hence reduce greenhouse gas emissions. Agron Sustain Dev 28:465-472. doi:10.1051/agro:2008030

Khan DF, Peoples MB, Schwenke GD, Felton WL, Chen D, Herridge DF (2003) Effects of below-ground nitrogen on $\mathrm{N}$ balances of field-grown fababean, chickpea, and barley. Aust J Agric Res 54:333-340

Kim S, Dale BE (2005) Life cycle assessment of various cropping systems utilized for producing biofuels: bioethanol and biodiesel. Biomass Bioenerg 29:426-439. doi:10.1016/j.biombioe.2005.06. 004

Lemke RL, Zhong Z, Campbell CA, Zentner RP (2007) Can pulse crops play a role in mitigating greenhouse gases from North American agriculture? Agron J 99:1719-1725. doi:10.2134/agronj2006. $0327 \mathrm{~s}$

Lithourgidis AS, Dhima KV, Vasilakoglou IB, Dordas CA, Yiakoulaki MD (2007) Sustainable production of barley and wheat by intercropping common vetch. Agron Sustain Dev 27:95-99. doi:10.1051/agro:2006033

Lorenz AJ, Gustafson TJ, Coors JG, Leon N (2010) Breeding maize for a bioeconomy: A literature survey examining harvest index and stover yield and their relationship to grain yield. Crop Sci 50:1-12. doi:10.2135/cropsci2009.02.0086
Luo YQ, Zhou XH (2006) Soil respiration and the environment. Academic Press, Burlington, pp 216-247

Nieder R, Benbi DK (2008) Carbon and nitrogen in the terrestrial environment. Springer, Heidelberg and New York, pp 430-442

Oelhermann M, Echarte L, Vachon K, Dubois C (2009) The role of complex agroecosystems in sequestering carbon and mitigating global warming. Earth Environ Sci 6:20-31. doi:10.1088/1755$1307 / 6 / 24 / 242031$

Parkin TB, Kaspar TC, Senwo Z, Prueger JH, Hatfield JL (2005) Relationship of soil respiration to crop and landscape in the Walnut Creek Watershed. J Hydrometeor 6:812-824. doi:10.1175/ JHM459.1

Qin AZ, Huang GB, Chai Q, Yu AZ, Huang P (2013) Grain yield and soil respiratory response to intercropping systems on arid land. Field Crops Res 144:1-10. doi:10.1016/j.fcr.2012.12.005

Shi PL, Zhang XZ, Zhong ZM, Ouyang H (2006) Diurnal and seasonal variability of soil $\mathrm{CO}_{2}$ efflux in a crop land ecosystem on the Tibetan Plateau. Agr Forest Meteorol 137:220-233. doi:10.1016/ j.agrformet.2006.02.008

Sullivan P (1998) Intercropping principles and production practices: Appropriate technology transfer for rural areas. Fayetteville, AR, pp 56-71

Tilman D, Cassman KG, Matson PA, Naylor R, Polasky S (2002) Agricultural sustainability and intensive production practices. Nature 418:671-677

Yang JY, Drury CF, Yang XM, De Jong R, Huffman EC, Campbell CA, Kirkwood V (2010) Estimating biological $\mathrm{N}_{2}$ fixation in Canadian agricultural land using legume yields. Agric Ecosyst Environ 137:192-20

Zhai LM, Liu HB, Zhang JZ, Huang J, Wang BR (2011) Long-term application of organic manure and mineral fertilizer on $\mathrm{N}_{2} \mathrm{O}$ and $\mathrm{CO}_{2}$ emissions in a red soil from cultivated maize-wheat rotation in China. J Integr Agr 10:1748-1757. doi:10.1016/S16712927(11)60174-0

Zhang JL (2007) Barriers to water markets in the Heihe River basin in northwest China. Agric Water Manag 87:32-40. doi:10.1016/j. agwat.2006.05.020

Zhang FS, Li L (2003) Using competitive and facilitative interactions in intercropping systems enhances crop productivity and nutrient use efficiency. Plant Soil 248:305-312. doi:10.1023/ A:1022352229863 